\title{
Karoo fracking and the Christian faith community
}

\begin{tabular}{|c|c|}
\hline \multicolumn{2}{|c|}{$\begin{array}{l}\text { Authors: } \\
\text { Gerrit van Tonder }{ }^{1 \dagger} \\
\text { Roger Tucker }{ }^{2}\end{array}$} \\
\hline $\begin{array}{l}\text { Affiliations: } \\
{ }^{1} \text { Department o } \\
\text { University of th } \\
\text { South Africa }\end{array}$ & $\begin{array}{l}\text { f Hydrology, } \\
\text { ne Free State, }\end{array}$ \\
\hline $\begin{array}{l}{ }^{2} \text { Department o } \\
\text { Theology, Univ } \\
\text { Free State, Sou }\end{array}$ & $\begin{array}{l}\text { Practical } \\
\text { ersity of the } \\
\text { th Africa }\end{array}$ \\
\hline $\begin{array}{l}\text { Note: } \\
\text { This article was } \\
\text { paper delivere } \\
\text { conference of } \\
\text { for Practical Th } \\
\text { January } 2014 \text { a } \\
\text { of Pretoria. The } \\
\text { addresses the } \\
\text { conference: Pr } \\
\text { and human wa }\end{array}$ & $\begin{array}{l}\text { s initially a } \\
d \text { at the Annual } \\
\text { the Society } \\
\text { heology on } 23 \\
\text { at the University } \\
\text { e article } \\
\text { theme of the } \\
\text { actical theology } \\
\text { aste in Africa. }\end{array}$ \\
\hline $\begin{array}{l}\text { This article is } p \\
\text { section Practic } \\
\text { of the Society } f \\
\text { Theology in So }\end{array}$ & $\begin{array}{l}\text { ublished in the } \\
\text { al Theology } \\
\text { for Practical } \\
\text { uth Africa. }\end{array}$ \\
\hline $\begin{array}{l}\text { Corresponden } \\
\text { Roger Tucker }\end{array}$ & ce to: \\
\hline $\begin{array}{l}\text { Email: } \\
\text { roger@tuckerz }\end{array}$ & a.com \\
\hline $\begin{array}{l}\text { Postal address } \\
3 \text { Waverley Ga } \\
\text { Waverley Road } \\
9301 \text {, Bloemfo } \\
\text { South Africa }\end{array}$ & $\begin{array}{l}\text { rdens, } 110 \\
\text {, Waverley } \\
\text { ntein, }\end{array}$ \\
\hline $\begin{array}{l}\text { Dates: } \\
\text { Received: } 05 \mathrm{~F} \\
\text { Accepted: } 07 \mathrm{~J} \\
\text { Published: } 13 \mathrm{C}\end{array}$ & $\begin{array}{l}\text { eb. } 2014 \\
\text { une } 2014 \\
\text { Oct. } 2014\end{array}$ \\
\hline $\begin{array}{l}\text { How to cite thi } \\
\text { Van Tonder, G. } \\
2014 \text {, 'Karoo fr } \\
\text { Christian faith } \\
\text { HTS Teologiese } \\
\text { Theological Stu } \\
\text { \#2631, } 8 \text { pages } \\
\text { org/10.4102/h }\end{array}$ & $\begin{array}{l}\text { is article: } \\
\text { \& Tucker, R., } \\
\text { acking and the } \\
\text { community', } \\
\text { Studies/ } \\
\text { udies } 70(2) \text {, Art. } \\
\text { s. http://dx.doi. } \\
\text { ts.v70i2.2631 }\end{array}$ \\
\hline $\begin{array}{l}\text { Copyright: } \\
\text { (C) 2014. The A } \\
\text { Licensee: AOSI } \\
\text { OpenJournals. } \\
\text { is licensed und } \\
\text { Creative Comm } \\
\text { Attribution Lice }\end{array}$ & $\begin{array}{l}\text { uthors. } \\
\text { S } \\
\text { This work } \\
\text { ler the } \\
\text { nons } \\
\text { ense. }\end{array}$ \\
\hline Read online: & $\begin{array}{l}\text { Scan this QR } \\
\text { code with your } \\
\text { smart phone or } \\
\text { mobile device } \\
\text { to read online. }\end{array}$ \\
\hline
\end{tabular}

One of the challenges for Practical Theology in Africa is to engage with the continent's concerns and challenges in such a way that the kingdom of God is realised in society and is seen to be relevant to these issues by people who are outside of academia. In our article, which was first presented at the Practical Theology congress in Pretoria in January 2014, the authors seek to demonstrate how this may be accomplished by applying insights to one concern, namely 'fracking'. The objective is to mobilise the influential Christian faith community in South Africa to begin to exercise prophetic discernment concerning fracking in the Karoo. The fracking debate is a product of the tension between the environmental degradation that its waste products may cause, on the one hand, and, on the other, the greater energy demands of a rapidly increasing world population along with its expectations of an ever-increasing standard of living. Shale gas fracking in the Karoo region of South Africa promises to make vast reserves of oil and gas available to help meet a significant percentage of the country's energy needs for many years to come, and so thus aid development and contribute to raising the standard of living of many people. Yet the management of the waste products associated with the process is an area of serious environmental concern. The article aims to apprise the South African Christian faith community of the technology and risks involved. Theological guidelines are presented by which fracking's benefits and dangers can be interrogated so that the community may come to an informed decision as to whether or not to support fracking.

\section{Introduction}

\section{Communicating Practical Theology discourse}

At the recent Annual Meeting of the Society for Practical Theology in South Africa (2014), the title of one of the keynote sessions was 'Are we wasting our theology in our continent?' The authors of the present article believe that this will be the case unless practical theologians in Africa engage with the continent's concerns and challenges in such a way that the kingdom of God is seen to be relevant by those who do not move in academic theological circles. Despite the admirable efforts of some academics, which have proved very useful in establishing a theological discourse, much greater effort is needed to communicate the method and findings of Practical Theology in language that will enable it to be understood and applied by grass-root Christians (Tucker 2011:9). To this end, we have also mixed-and-matched various practical theological frameworks, such as Heyns and Pieterse's (1990), Van der Ven's (1993), Heitink's (1999), and Osmer's (2008) without undue explanation, because of the need for brevity in writing a journal article and in the interests of simplicity of communication to the target audience, most of whom are not interested in Practical Theology theory or in theological discourse, but in its application to their work and the decisions they have to make.

The target groups of this article are religious and church-oriented scientists, engineers, geologists, decision-makers in the business world and government, and ordinary clergy. Perhaps we are breaking new ground by venturing into the area of the applied 'hard' sciences such as engineering, hydrology and geology. Yet the Kingdom establishes a perspective that 'comprehends all God's acts, disclosing their essential significance, and at the same time indicating the ultimate purpose of all things' (Heyns 1980:4, 5). Dreyer (2010:3) comments accordingly, '[w]e have a responsibility to the "common good" in our contexts, in the societies and regions in which we live and even

Note: †Prof Gerrit van Tonder died of a sudden heart attack on 22 April 2014, leaving behind his beloved wife Fransie, and his children Sanri and Gideon. He was 61 . Gerrit van Tonder started working as lecturer and researcher at the Institute for Groundwater Studies (IGS), a faculty of the University of the Free State in South Africa, on 01 January 1976. He specialised in hydraulics and focused on the determination of aquifer parameters and groundwater modelling. In the last few years, Gerrit was the most senior professor at IGS. He determination of aquifer parameters and groundwater modelling. In the last few years, Gerrit was the most senior professor at IGS. He
tutored more than 60 master's and PhD students in his career. He was also highly regarded in groundwater circles in South Africa. Many tutored more than 60 master's and PhD students in his career. He was also highly regarded in groundwater circles in South Africa. Many
alumni returned to him for advice several times. He was passionate when it came to the protection of groundwater. Van Tonder had alumni returned to him for advice several times. He was passionate when it came to the protection of groundwater. Van Tonder had
said repeatedly that fracking would not affect or harm the groundwater. As a professor at the University of the Free State's Institute said repeatedly that fracking would not affect or harm the groundwater. As a professor at the University of the Free State's Institute
for Groundwater Studies, his opinion carried real weight. But then in May 2012 he dropped a bombshell: If fracking was allowed to go ahead during exploration, using poisonous chemicals, it could be a catastrophe, he said. He became known in the media as the ' $U$-turn Professor'. Thus in the past few years he became famous as the professor who wanted to ensure more groundwater protection during fracking. Outside of his professional career, he also kept himself busy with nature, the thousands of roses he planted on his farm, Little Ranch, and the donkeys on his farm. 
globally (e.g. regarding environmental policies)'. That such sentiments are increasingly being shared by practical theologians is indicated by the theme of the aforementioned Practical Theology meeting which was 'Practical Theology in Africa and human waste.'

Practical Theology is the appropriate theological tool for communicating kingdom of God insights to society, as its objective is to relate theological insights to empirical facts in a methodological and systematic manner (Van der Ven 1994:32), using a multidisciplinary approach. In this context, it should be noted that the content of the article is determined by the fact that the authors follow this multidisciplinary approach as one is a practical theologian and the other a professor of hydrology.

Because Practical Theology is an operational science (Heyns \& Pieterse 1990:9), it operates by proposing hypotheses that can be tested. The central hypothesis of the present research into hydraulic fracturing (commonly called 'fracking') is that eco-theological principles may be used to help to prophetically discern the environmental issues connected with fracking and to guide the Christian faith community. An attempt is made to apply this 'testing' as objectively as possible. A problem is that the fracking issue seems to be highly emotive, which we are trying to avoid. In this respect, King's (2012) perceptive comment needs to be noted:

\begin{abstract}
The spectacular increase in North American natural gas reserves created by shale gas development makes shale gas a disruptive technology, threatening the profitability and continued development of other energy sources. Introduction of such a disruptive force as shale gas will invariably draw resistance, both monetary and political, to attack the disruptive source, or its enabler; hydraulic fracturing. Some 'anti-frack' charges in media articles and university studies are based in fact... other articles have demonstrated either a severe misunderstanding or an intentional misstatement of well development processes, apparently to attack the disruptive source. (p. 1)
\end{abstract}

\section{The critical need of the Christian faith community to investigate the fracking issue}

Practical Theology is a theory of crisis (Heitink 1999:2, 3). The fracking issue illustrates one symptom of the crisis of modernity that society, and therefore the church, faces in respect of the environment. The Christian faith community needs urgently to be given the tools to undertake prophetic discernment of the fracking issue in order to be mobilised to exert its influence. This view is highlighted by the fact that the South African (SA) government signalled in October 2013 that it was keen to start exploiting shale gas reserves in the Karoo by means of fracking. Mineral Resources Minister Shabangu is reported as having stated, 'by embarking on this process presented [sic] by hydraulic fracturing for the production of shale gas, we bring the country a step closer to the achievement of our objectives' (Stoddard 2013).

Fracking could benefit many in SA; but prior to this announcement, a 2012 government report on fracking by experts in the field had advised that the decision to proceed be delayed until further investigations could be completed (Department of Mineral Resources 2012:69). The current crisis arises because it is reported that none of the proposed investigations have been completed or even begun (Centre for Environmental Rights (CER) 2013)! Therefore the authors believe that every member of the Christian faith community in South Africa should be concerned about this seemingly precipitate decision to proceed with fracking. The church has the leadership and the organisation at grassroots level to promote mass awareness of the dangers of a hurried decision to proceed with fracking (Conradie 2011:15).

To understand the benefits and dangers, to be able to make a considered decision, and to comprehend the importance of arriving at a correct decision, we must first understand what fracking involves. This is important as the dangers of fracking in the Karoo are potentially greater than in other parts of the globe, where the process causes only minor problems owing to operational errors (see Golder Associates 2011; King 2012). The reason is that South Africa is the only country known where shale gas deposits have been intruded by dolerite. This makes the situation in the Karoo unique and thus the extrapolation of knowledge from elsewhere in the world to the area should be applied with caution (Vermeulen 2012:149-150).

\section{The process}

Hydraulic fracturing is a process that enables the extraction of shale gas from low-permeability ${ }^{1}$ unconventional reservoirs such as shale. In engineering terms, fracking comprises a precise activity that is limited only to fluid action in initiating and extending cracks in the gas-containing rock. This definition can create confusion because, for many concerned citizens, bloggers and environmentalists, fracking has come to represent nearly every phase of the well development cycle, from drilling to production (King 2012:4). The present article uses the commonly accepted term of 'fracking' to describe the whole process.

Fracking creates fissures in low-permeability shale that allows entrapped gas to flow via a pressure gradient (owing to the weight of rock above) from the highly pressured shale into the lower pressure within the borehole. Fluid and gas do not naturally escape from a rock of low permeability, such as the shales found in the Karoo, even when pierced by a conventional oil-drilling borehole.

The process begins with drilling a vertical borehole down to reach the shale ${ }^{2}$ layer containing oil or gas, which in much of the Karoo is $3 \mathrm{~km}$ down. At this depth, one or more horizontal boreholes are then drilled for up to $4 \mathrm{~km}$. Fracking fluid, which contains a mixture of water, sand, steel, plastic ball bearings, and ceramic pieces, is pumped into the boreholes.

1.Permeability describes the ability of a substance (such as water, oil or gas) to move through a rock, from one pore space to the next.

2.Shale is a rock that is chemically similar to clay but has been altered by heat and pressure over millions of years to become flaky and hard. 
Perforation (perf) guns are inserted into the boreholes and then fired, which causes the hard material in the fracking fluid to pierce holes in the horizontal borehole casing and to penetrate into the surrounding rock, fracturing it for as much as $100 \mathrm{~m}$. When the pressure is released, gas along with water is able to flow out of the shale into the fissures, then into the borehole and rise to the surface where it is collected and stored. The first fluid coming out of the pipe is called flowback and comprises mainly fracking fluid. Several days later, a gas and water mixture emerges that is known as produced fluid (Department of Mineral Resources 2012:20ff., Dobb 2013:37).

\section{The prophetic discernment}

The Christian faith community has a God-given mandate to interrogate this process:

Postmodern (Christian) theologians no longer cede the question of what the world is to science alone... although scientific theory is carefully heeded... it is transformed... when it is read theologically. (Clayton 2003:204, 205)

This is because science, engineering and economics are not essentially concerned with God's moral nature, intentions or eternal plans. Applying such ethical concerns from theology to technology may be called prophetic discernment, which is the normative task of Christian Practical Theology according to Osmer (2008:129ff.). Such discernment uses a hermeneutic based upon God's Word (the Christian Bible) and announces this word to the covenant community of God's people - the church (Osmer 2008:132).

There are a number of biblical concepts from which to choose an appropriate hermeneutic on which to base this discernment. Postmodern deconstructionist 'theologies' relating to mankind's stewardship of creation, such as Clayton's (2003) panentheistic approach in 'God and the World' and Wallace's (2001) pneumatological enfleshment of God in everything, are not appropriate for our target audience. To be convincing to such an audience, the hermeneutic needs to be easily understandable, systematic and clearly based upon Christian scripture, which many take as their final authority concerning belief and conduct. Therefore we have opted for a more conservative, evangelical reformed theology that can be perceived as coming directly from a biblical hermeneutic. From an overwhelming complexity of ecotheologies, such as those presented by Conradie (2006:69-82), we have chosen three easily communicated 'earth-care' metaphors termed fruitfulness, earth-keeping and Sabbath renewal, modifying and developing a simple framework propounded by DeWitt (see e.g. 1992, 2011).

\section{Fruitfulness}

In Genesis 1:28, God commands humankind to 'be fruitful ...' The fruitfulness metaphor indicates that God created the Earth to give all human beings the opportunity to realise the full potential for which God created them (Brueggemann 1997:528ff.). The metaphor emphasises that the interests of animals cannot be valued above those of humankind. 'There is a legitimate anthropocentrism' contained within Genesis 1:28 (Conradie 2006:80, quoting Welker 1999:70). In biblical terms, this potential is primarily realised through the abundant life that Jesus came to give humankind (Jn 10:10), but also through education, health care, adequate accommodation, technological development and scientific discovery, sport, economic provision, food security, productive labour, and loving and fulfilling social relationships.

The 'bourgeois subjects' (Heitink 1999:30ff.) of the developed world must take care about advocating the making of decisions that debar the unemployed poor of South Africa from extended lifespans, and expanded consciousness as the result of improved health-care, education, information technology and books. What right have we to dictate to them that they should not enter the consumer society and enjoy a few of the comforts and luxuries that we enjoy, and the security of comfortable home-ownership, electricity and accessible water? What right have we, who have the opportunity to stand at the apex of fulfilment of Maslow's (1943:370ff.) hierarchy of needs, to tell them they must always be condemned to the lowest rung of mere survival? In doing so, might not we be pandering to some romantic notional ideal that we have of the Enlightenment's 'noble savage's' relationship to nature and the need to preserve an environment that we have already over exploited?

\section{Earth-keeping}

When the Creator blessed humankind and commanded them to be fruitful, he must have been aware, with his foreknowledge and omniscience, that it would involve destruction and exploitation of pristine habitat. Practically anything we do has always modified or destroyed something of creation, such as the almost conclusively proven overhunting of early Holocene mega-faunas by our ancestors (Palmer 2005:67), as well as the legitimate building of cities, farming, monoculture grazing, constructing dams, creating gardens and parks etc. There will always be a tradeoff between the legitimate demands of people as against the sustaining of earth's diversity, productivity and the legitimate rights of the creatures that, we shall see in the next paragraph, human beings were created to protect.

This produces a tension that will always be unresolved since we read in Genesis 2:15 that God has appointed men and women not only to develop his earth creatively but also to care for it. This means that after the fall they are now, in addition, to seek to limit its degradation and protect it from irreversible destruction. Genesis 2:15 reads ' $t$ ] he Lord God... put him [man] in the Garden of Eden to ... take care of it.' 'Care' translates the word שֵָָׁ (shāmar). The basic concept of the root of this Hebrew verb is 'to keep by exercising great care over' (Harris, Archer \& Waltke 1980:n.p.). Humankind was created to keep the Garden of Eden by caring for it as any caring gardener would (DeWitt 2011:84). Eden is representative of the whole created 
world (Alexander 2008:loc. 24945) where our first ancestors were set the task of nurturing the global ecosystem over which God had given them authority (Fretheim 1994:346). Good stewardship means making decisions, whenever possible, that keep, guard, protect, maintain and sustainably develop the world in the light of humankind's legitimate progress to increasing fruitfulness. The earth-keeping metaphor forces us to ask, ' $[h]$ ow then can we obey God's command to be fruitful whilst allowing the rest of His creation to be fruitful?' (DeWitt 2011:73).

There is a need to be continually vigilant about earth-care because there is a force both within and outside of humankind that nullifies the Creator's intentions and seeks to greedily and selfishly over-exploit the earth and the food chain (as described in Ps 104) to the point of destruction. In the Old Testament, this force of chaos is called Tiamat, Leviathan, Rahab, Yam and Mot [death] (Brueggemann 1997:534ff.). In the church tradition, based on the New Testament, this force or personality is termed 'death, sin, the world, the flesh and the devil', and is represented in the book of Revelation by the four horsemen of the Apocalypse.

\section{Sabbath renewal}

God created the Universe and the Earth so that it would naturally renew itself if managed properly and given sufficient time, a view celebrated by the metaphor of Sabbath observance. Exodus 20:8ff. links Sabbath observance with the fact that God himself rested on the seventh day (Gn 2:1-3). In Exodus 23:12, the purpose of the resting is given as refreshing (נָָּׁ naphash) and the renewal that this brings. This Sabbath principle is later extended to looking after the land by allowing it to rest from usage (Lv 25:2-6) every seven years (Brueggemann 1997:189; Currid, Kiuchi \& Sklar 2008:loc. 42947-42954), and is enshrined in the command to celebrate the 'Year of Jubilee' every 49 or 50 years in Leviticus 25:10ff. Jesus extended the Sabbatic principle into the New Testament through identifying the results of his mission with the Year of Jubilee (Lk 4:28) and by calling himself the 'Lord of the Sabbath' (Lk 6:5).

As such, the Sabbath may be seen as a metaphor of God's desire for humankind to delight in his creation and to give it rest to allow it to be refreshed and renewed both by his spirit and its God-imparted, inbuilt renewing ability (Moltmann 1985:6; Fung 2006:317). All those who call Jesus 'Lord' because they have entered into the 'Sabbath rest' mentioned in Hebrews 4: 9 (Chapman 2008: loc. 306178, 308429ff.) have a responsibility to care for his creation by working for its renewal when it is damaged. Consequently, the Sabbath renewal metaphor leads us to ask, 'How can we obey God's command to be fruitful whilst at the same time ensuring that doing so does not permanently destroy the fruitfulness of God's creation but allows it to be renewed?'

To answer this question realistically, we must be aware that the process of renewal has always involved death, destruction and recycling in God's Universe, such as in super-novae releasing the dust that forms new stars (McGrath 2009:164); earthquake-inducing tectonic processes that create new continents and lands; consuming fire-storms from igneous intrusions congealing to form new land and rich soils, the deposition of vitiated soil through erosion by seas, rivers, wind or glaciers producing new fertile soils; and the processes of extinction, death and decay that enable new life to develop from the old by the enrichment brought about by microbiological organisms and fungi. Humankind was intended to be an agent of this renewal, given the ability to hasten the process through letting land lie fallow, burning trees and grasses, the application of human and animal excrement, and the growth of crops, such as legumes, that added new minerals to the soil. The process might also include the recycling of mine tips, treatment of acid mine drainage, transportation and addition of fresh soil, and the planting of cleansing grasses and trees. Yet ultimately we have to accept that, although we must allow and instigate renewal whenever we can, the destruction we have caused to realise our own fruitfulness will only be rectified eschatologically at the ultimate Sabbath renewal of the parousia, when all things will be made new (Rv 21:5).

\section{How might these metaphors and the insights they bring be used to interrogate the process and results of fracking?}

\section{Using the fruitfulness metaphor}

The fruitfulness metaphor raises the question: Will fracking in the Karoo produce abundance, progress, and development that will holistically benefit and enrich all South Africans or the world's biosphere?

Fracking promises to enable many South Africans to enjoy a more fulfilled and fruitful life by providing employment and the opportunity to engage in more skilled and remunerative work. The process will provide job opportunities via the labour required for creating the necessary infrastructure, and processing and distributing the resulting gas. This will have a multiplier effect throughout the economy that will reduce the high level of unemployment in South Africa, and motivate and facilitate skills training. Over and above potential employment opportunities, the State would benefit from taxes and royalties. Revenue (sales and sales tax) will also be generated from direct and indirect supplies from the retail industry, food services, and the hospitality and housing industries (although most of the drilling and production equipment would probably be sourced from abroad) (Department of Mineral Resources 2012:54).

How much the project will contribute to reducing unemployment is uncertain since the extent of the shale gas is impossible to quantify accurately (Department of Mineral Resources 2012:1). The total potential gas reserve in the Karoo shales is currently estimated to be 13734 trillion cubic metres $\left(\mathrm{Tm}^{3}\right)$, making it the fifth largest shale gas field in the world (Steyl \& Van Tonder 2013:7), of which $850 \mathrm{Tm}^{3}$ may eventually be produced (Department of Mineral Resources 2012:3). An Econometrix study commissioned by Shell found that if 
there were $566 \mathrm{Tm}^{3}$ of economically viable shale gas, this would translate into R80 billion, or 3.3\% of gross domestic product (GDP). If there were $1133 \mathrm{Tm}^{3}$, this would translate into R200bn, or $9.6 \%$ of GDP. The first estimate could result in 300000 jobs and the second, 700000 (Gosling 2014:n.p.).

In addition, fracking promises to augment South Africa's energy resources by reducing, '... our dependence on coal ... [and] the "carbon intensity" of our energy systems... improve "security of supply" by developing indigenous resources; and... expand our national capacity to generate electricity' (Department of Mineral Resources 2012:25).

Even though this process would be spread over a period of 20-30 years it clearly has the potential to have a major impact on the national economy. Although Income Tax and Royalty accruing to the national fiscus depend on profitability it is expected that such amounts will run into tens or hundreds of millions of Rand, augmented by VAT (Department of Mineral Resources 2012:2).

The overseas investment needed will also be beneficial in this regard.

Environmental benefits could also ensue by reducing the 'carbon intensity' of our energy systems. Coal is a highpollutant form of energy and produces much carbon dioxide, however carefully it is utilised. Converting shale gas to energy will greatly reduce South Africa's carbon footprint and decrease health risks owing to atmospheric pollution. It may also follow that new nuclear power plants will not need to be built, so decreasing the risk of radioactive leakage, in a Chernobyl- or Long Island-type of meltdown and the danger from radioactive waste disposal.

Finally: in an ever-increasingly uncertain world, the discovery of an unconventional terrestrial gas resource may enable South Africa to enter a new age of energy independence. South Africa's 'security of supply' would consequently improve by developing indigenous energy resources, and ... 'expand our national capacity to generate electricity' (Department of Mineral Resources 2012:25).

Thus using the fruitfulness metaphor as a normative standard by which to judge fracking indicates that it will have many benefits for South Africa.

\section{Using the 'earth-keeping' and 'Sabbath renewal' metaphors}

There are no human endeavours without risk. 'Consequences range from slight and practically unavoidable [sic] to severe and avoidable at all costs' (King 2012:1, 2). Therefore the 'earth-keeping' metaphor indicates that the appropriate question to ask is: Will fracking in the Karoo enable humankind to manage the Karoo so that its fecundity and beauty is not destroyed?; whilst the Sabbath-renewal metaphor leads us to ask, Will fracking in the Karoo allow it to recover from whatever damage may be caused? What, then, are some of the factors that should be examined? We do so by using the two earth-care metaphors of 'earth-keeping' and 'Sabbath renewal'.
The Karoo is a productive, fragile, unique environment: A major problem is that the Karoo is a fragile and unique environment. Yet, owing to mineral-rich soils and nutritious plants, the Karoo is home to just over one million people living on farms and in some 100 settlements. It supplies 30\% of South Africa's red meat, $30 \%$ of its wool, and $100 \%$ of its mohair (Nel \& Hill 2008:2275). It is fragile because water is scarce and most of its people are completely dependent on water from artesian aquifers. It is unique because it contains more than 6000 plant species of which $40 \%$ exist nowhere else (Du Toit 2013:n.p.). It is naturally fruitful and productive and has been made more so by human activities such as irrigation, wind-powered water pumps and careful, creative husbandry. But because of its fragility and uniqueness, it must be protected and treated with greater care than many other areas, lest its productivity be destroyed. It must therefore be flagged as an 'earth-care fragile zone', to be handled with care. The problems discussed below indicate that fracking may damage this fragile, handle-with-care environment and infringe the principles of the earth-keeping metaphor.

Disposal of toxic waste products: The above issue arises because fracking fluid $^{3}$ and all other waste products produced by fracking are to some degree toxic and could consequently harm the environment, agriculture and public health (Hammer \& Van Briesen 2012:1, Steyl \& Van Tonder 2013:8). Flowback fluid is very toxic; not only does it contain high concentrations of fracking fluid but also high concentrations of hydrogen sulphide, radioactive $\mathrm{r}^{4}$ materials and soil-sterilising salts ${ }^{5}$ which are abundant in most subterranean rock layers. Eventually, the amount of manmade compounds coming out of the borehole diminishes, although the emerging water is usually slightly radioactive, and still contains the harmful natural salts and hydrogen sulphide.

The first point of 'earth-keeping' concern is the disposal of both flowback and produced water and distinguishing between the two, as the disposal process depends upon the classification. Usually, '[v]ery little treatment is performed on produced water' (United States Department of Energy 2011, 2013:2). The sooner that water coming out of the borehole can be classified as produced water, the less costly it is to treat. The dividing line between flowback and produced water is not always clear. Therefore the decision as to when flowback

3.A recent investigation by the House of Representatives in the United States of America (USA) found that 750 chemical compounds were used from 2005 to 2009 in fracking fluid. This included 29 chemicals that are known as, or are possible, in fracking fluid. This included 29 chemicals that are known as, or are possible,
human carcinogens. BTEX compounds appeared in 60 of the hydraulic fracturing human carcinogens. BTEX compounds appeared in 60 of the hydraulic fracturing
products used in this period (Steyl \& Van Tonder 2013:10). 'BTEX is an acronym products used in this period (Steyl \& Van Tonder 2013:10). 'BTEX is an acronym
that stands for benzene, toluene, ethylbenzene and xylenes. These compounds are some of the volatile organic compounds (VOCs) found in petroleum derivatives such as petrol. Toluene, ethylbenzene and xylenes have harmful effects on the central nervous system [and] are notorious [owing] to the contamination of soi and groundwater with these compounds. Contamination typically occurs nea petroleum and natural gas production sites, petrol stations and other areas with underground storage tanks (USTs) or above-ground storage tanks (ASTs) containing petrol or other petroleum-related products' (European Environment Agency, 2010, BTEX).

4.This possibility is illustrated by the uranium-enriched Karoo rocks found near Edenburg, Beaufort West and Victoria West, which may be the result of the process called mineralisation, where upward-seeping water deposits radioactive elements in the host rocks (Norman \& Whitfield 2006:116ff.).

5.For the possibility of this, see Vermeulen (2012:152) 
is categorised as produced water needs to be supervised by a government agency in order to regulate the temptation to economise at the expense of safety.

The second point is a 'Sabbath renewal' concern and involves the permanent disposal of flowback. The normal method, as practiced in Dakota, is to separate this 'dirty' [sic] water from the oil or gas and then store it in three-storey-high tanks from which it is regularly pumped into trucks which then transport it to a site where it is pumped deep below the surface to permanently and safely dispose of it (Dobb 2013:35, 36). In any environment - but especially an unregulated, loosely monitored one - it may be dumped in the wrong place, or spills, leaks and traffic accidents could occur (King 2012:32).

Another question that arises is whether it will stay in the supposedly safe location and not migrate to contaminate water used for irrigation and drinking. As mentioned below, the geology and geomorphology of the Karoo area poses a very real danger that any liquid that is pumped into the earth, no matter how deep, will return to the surface to pollute the water table and so contaminate the aquifer and in turn the water used for irrigation. Either way, contamination of Karoo aquifers could occur and, via irrigation and subsurface water from artesian boreholes, result in sterilisation of surface soils and subsequent destruction of the Karoo's productivity and the pollution of potable water. It must be emphasised that such environmental damage has occurred in parts of the USA where fracking is practiced, even in its highly supervised and regulated regime (Dobb 2013:37).

Leakage of fluids from boreholes into surrounding rock with long-term adverse consequences: Leaking of fracking fluid into subterranean rocks in the shale layer could also be a problem as the fluid may migrate into the surface aquifer to cause damage. Leakage into rocks surrounding the borehole is supposedly prevented by means of a cement and steel borehole casing. Yet this does not mitigate the problem of what happens to the fluid that penetrates into the shale layer during the initial fracking. Often, over 50\% of this fluid remains in the shale ${ }^{6}$ (King 2012:10), to potentially migrate upwards to the surface of the fragile Karoo.

'Sabbath renewal' is also endangered because of borehole deterioration after the gas extraction process is completed (Glass 2011:3). Over the years, cement shrinks and cracks, and steel casings corrode (Ingraffea 2009:n.p.). It follows that any fluid remaining in the borehole after production ceases could leak into the surrounding rock, potentially contaminating the water table above with all the adverse environmental implications mentioned above. This aspect may make the renewal of damage caused by the waste products of fracking difficult, if not impossible, because polluted water may continue to come to the surface at unpredictable locations for many years after fracking is finished, because of the geomorphology and geology of the Karoo.

6.The amount of fracking fluid recovered as flowback may range from as little as $5 \%$ in the Haynesville shale to as much as $50 \%$ in areas of the Barnett and the Marcellus shales (King 2012:10).
Geology and geomorphology of the Karoo: In contrast to other areas where fracking is practiced, most of the above problems occur because of the particular geology and geomorphology of the Karoo. This makes it a real possibility that fracking fluid that has leaked into subterranean rocks from the fracking process, or from flowback and produced water from the depths, will migrate upwards to the surface to pollute the aquifer and eventually contaminate the fragile soils and the subsurface water that supports agriculture and the people and animals of the Karoo. The prime reason for this possibility is that the dominant subsurface geomorphological feature of the Karroo rocks is that of an artesian basin. In such a basin, where the rocks at the centre are at a much greater depth than those on the rim, pressure is exerted on any underground water near the centre of the basin to come to the surface, either as slow leaks, springs or even fountains. Proof of this is the natural mineral hot springs that are found all over the Karoo. Twelve thermal springs are located in the Karoo, most arising alongside dolerite dykes rising from depths of $600 \mathrm{~m}$ - $1300 \mathrm{~m}$ (Vermeulen 2012:152). Although these thermal springs are of shallow origin, they illustrate the artesian upward pressure upon subsurface water in the Karoo.

This process of underground water coming to the surface is facilitated by the geology. The Karoo Supergroup underlies much of the Karoo, and consists of thick layers of sedimentary $^{7}$ rock intruded by igneous ${ }^{8}$ rock (Steyl \& Van Tonder 2013:7). The igneous rock comprises many dolerite ${ }^{9}$ sills, ${ }^{10}$ dykes $^{11}$ and kimberlite ${ }^{12}$ pipes. Faults (fissures in the rock strata) are also common in the southern section of the western Karoo (Department of Mineral Resources 2012:2, 4,42 ). These dolerite sills and dykes and kimberlite pipes provide pathways for fluid migration because they have fractured the rocks into which they intruded at the contact zone, and have pierced existing rock cap barriers that might prevent upward migration. Similarly faults, which are by nature fractures anyway, also provide fluid migration pathways. Sills and dykes in parts of the Karoo, such as found in the Trompsburg Igneous Complex, occur at depths from $1800 \mathrm{~m}$ - $3000 \mathrm{~m}$ (Norman \& Whitfield 2006:114). These features make it easy for water to migrate upwards from the depths to the surface along fracture zones. In addition, as these intrusions and faults not only provide vertical but also lateral pathways for water migration, the water may emerge

7.Sedimentary rocks contain mineral grains derived from the erosion of pre-existing rock that have then been deposited by water or wind and rocks composed of chemical and organic sediments. They are usually deposited as layers of soft chemical and organic sediments. They are usually deposited as layers of soft
muds, clays and coarse unconsolidated sandstones, and then form hard rock at muds, clays and coarse unconsolidated sandstones, and then form hard rock
considerable depths via the resultant pressure (Norman \& Whitfield 2006:15).

8.Igneous rocks form when molten magma, generated deep below the surface, rises to shallower levels and then cools. If magma reaches the surface, it generally erupts as volcanic lava. Igneous rocks that do not reach the surface cool to form sills, dykes or large underground plutons (Norman \& Whitfield 2006:14).

9.Dolerite is a medium-grained, dark-coloured igneous rock.

10.A sill is formed by liquid magma that has intruded more or less horizontally between layers of sedimentary rock before cooling.

11.A dyke is formed by liquid magma that intrudes through vertical fissures to form vertical walls of rock on cooling.

12.Kimberlite is a coarse-grained igneous rock that intrudes from great depths and sometimes contains diamonds. 
at unpredictable locations far removed from the original fracking site.

The above factors suggest that the earth-keeping principle may well be transgressed. The problem is that no one can predict, at this stage, that it will not occur, or how extensive will be the damage or where or how wide the area will be that is affected, if it does occur. In addition there is evidence to suggest that Sabbath renewal may not be possible, not only because of the indeterminacy of the factors mentioned in the previous sentence, but also because continuous, slow pollution may occur for many years after the fracking process is completed.

\section{Conclusion}

Shale gas is an important segment of energy production in the USA and could have the same impact in South Africa. In considering fracking, we are dealing with a matter on which the welfare of many people in South Africa may depend. The effects of a ban, moratorium or stringent regulations concerning fracking will reduce economic opportunity in South Africa. On the other hand, the environmental hazards for the Karoo may be equally damaging (Department of Mineral Resources 2012:59). At this stage, resolution of this conundrum is uncertain. This Practical Theological interrogation only presents an initial overview of some of the problems. One journal article cannot deal with the extensive eco-theological hermeneutics or with all the empirical environmental problems. The tentative nature of our conclusions derives from three considerations:

Firstly, other biblical hermeneutics that may be employed to consider the matter of fracking might arrive at different conclusions. The deductions reached from applying the earth-care metaphors depend on a qualitative assessment and are therefore necessarily subjective. Perhaps our choice of the three earth-care metaphors has to some extent decided the outcome of the investigation.

Secondly, the technical literature on fracking is extensive, addressing nearly every aspect of shale gas and oil development, with over 550 papers on shale fracturing and 3000 on all aspects of horizontal wells (King 2012:3). The engineering, scientific and technical experts concerned dispute many aspects, reports and research results. Perhaps, in the future, some theories might be converted into more objective, truly empirical concepts that are observable, measurable and scientifically acceptable and testable (Heyns \& Pieterse 1990:78; Van der Ven 1993:134). The tool for achieving this would probably be the risk assessment methodology that is being developed, among other places, in New Zealand and the USA (Gough 1997; Department of Mineral Resources 2012:60).

Lastly, it is certain that the technology involved with fracking will improve and result in a safer environmental process in the future. Already, techniques have greatly improved and former problems addressed. For instance, sounder casings are beginning to be used for boreholes, along with more environmentally friendly chemicals, and modern treatment facilities are being built to remove salts from the flowback water (Vermeulen 2012:154, 155). This said, the ecotheological hermeneutical framework we have employed to interrogate the fracking process leads to the conclusion that, despite the fruitfulness it may confer on many people in South Africa, adverse consequences will affect the Karoo environment. More employment may be created in South Africa - yet how many inhabitants of the Karoo will lose agricultural employment? What will the health bill be? What losses of natural diversity might occur? Will tourism suffer?

We conclude therefore that the possible environmental dangers are so great that the ultimate deciding factor must be the answer to the question 'How certain can you be that the benefits will outweigh the adverse results and that the damage will not be irreversible?' As long as credible doubt is expressed by recognised experts as to the damage that fracking may cause, or to the extent of that damage, then it is in the best interests of all if fracking is delayed - as the Department of Mineral Resources (2012) report proposed. In a democracy such as South Africa, where politicians make the decisions concerning fracking, and are probably influenced by short-term considerations, concerned Christians must endeavour to make sense of the basic facts in order to exercise an informed influence. We suggest that the Christian faith community needs to make a strategic intervention at all levels of government and business to ensure that the final decision will only be made when there is far greater certainty as to the outcome. Space does not permit us to explore the nature of this intervention, but maybe others will.

\section{Acknowledgements Competing interests}

The authors declare that they have no financial or personal relationship(s) that may have inappropriately influenced them in writing this article.

\section{Authors' contributions}

This article was written and sent for publication by R.T. (University of the Free State), based on a paper he presented in 2014 at the Annual Meeting of the Society for Practical Theology in South Africa in Pretoria. It was written with the advice and support of G.v.T. (University of the Free State).

\section{References}

Alexander, T., 2008, 'Genesis', in D. Lane, W. Grudem, J. Packer \& C. Collins (eds.), ESV Study Bible, Kindle version, loc. 17738-21400, (Study notes loc. 24657-28345), Crossway, Wheaton.

Brueggemann, W., 1997, Theology of the Old Testament, Fortress Press, Minneapolis. Centre for Environmental Rights (CER), 2013, Minimum Requirements for Regulation of Environmental Impacts of Fracking, viewed 30 January 2014, from http://www. cer.org.za

Chapman, D., 2008, 'Hebrews', in D. Lane, W. Grudem, J. Packer \& R. Schreiner (eds), ESV Study Bible, Kindle version, loc. 305945-306959, (Study notes loc. 308036-309702), Crossway, Wheaton.

Clayton, P., 2003, 'God and the world', in K. Vanhoozer (ed.), The Cambridge companion to Postmodern Theology, pp. 203-217, Cambridge University Press, Cambridge. http://dx.doi.org/10.1017/CCOL052179062X.012 
Conradie, E., 2006, Christianity and ecological theology, Sun Press, Stellenbosch. Conradie, E., 2011, Christianity and earthkeeping, Sun Press, Stellenbosch.

Currid, J., Kiuchi, N. \& Sklar, J., 2008, 'Leviticus', in D. Lane, W. Grudem, \& C. Collins C. (eds.), ESV Study Bible, Kindle Version, loc. 37600-39763, (Study notes loc. 41914-43092), Crossway, Wheaton.

Department of Mineral Resources, 2012, Report on investigation of hydraulic fracking in the Karoo basin of South Africa, July 2012, viewed 21 September 2013, from http://caxton.ofm.co.za/img/Depatmentuploads/Full\%20Report on \%20the investigation_of_hydraulic_fracturing_in_the_Karoo_Basin_of_South_Africa(2)

DeWitt, C., 1992, 'Respecting creation's integrity: Biblical principles for environmental responsibility', Firmament 3(3), 10-11, 20-21.

DeWitt, C., 2011, Earthwise, a guide to hopeful creation care, Faith Alive Christian Resources, Grand Rapids.

Dobb, E., 2013, 'New oil landscape', National Geographic, March, 28-59.

Dreyer, J.S., 2010, 'Practical Theology in South Africa: Recent developments and new challenges', keynote paper delivered at the conference of the Society for Practical Theology in South Africa, Perspectives and paradigms, Pretoria, 21 January.

Du Toit, J., 2013, 'Karoo - the beginner's guide', in Karoo Space, viewed 10 September $2013 \mathrm{from} \mathrm{http}: / /$ karoospace.co.za/karoo-the-beginners-guide/ (quoting Cape Wools and National Wool Growers Association, Mohair South Africa and the Karoo Development Foundation).

European Environment Agency, 2010, Benzene, toluene, ethylbenzene, xylene (as BTEX), viewed 25 February 2014, from http://glossary.eea.europa.eu/ terminology/concept_html?term=benzene,\%20toluene

Fretheim, T., 1994, 'The Book of Genesis', in L. Keck (ed.), The new interpreter's Bible, 1, pp. 321-674, Abingdon Press, Nashville.

Fung, C., 2006, 'Sabbath, 2006, The Alpha and Omega of God-Man partnership', Asia Journal of Theology 20(1), 182-204 and 20(2), 455.

Glass K., 2011, Shale gas and oil terminology explained: Technology, inputs \& operations, Carol Werner Environmental and Energy Study Institute, viewed 10 September 2013 from http://www.files.eesi.org/fracking_technology_120111.pdf

Golder Associates, 2011, Proposed South Western Karoo Basin Gas Exploration Project by Shell Exploration Company B.V, Background Information Document and Invitation to Comment Central Precinct, viewed 28 July 2013, from http://wwwstatic.shell.com/.../upstream/central-karoo-bid.pdf

Gosling, M., 2014, 'Fracking revenue still not clear - Shell', in IOLscitech, viewed 14 March 2014, from http://www.iol.co.za/scitech/science/environment?page $=4$

Gough, J., 1997, Environmental decision making and risk management, viewed 05 February 2014 from http://www.gdrc.org/decision/gough-edm_risk.html

Hammer R. \& Van Briesen, J., 2012, In fracking's wake, new rules are needed to protect our health and environment from contaminated wastewater, Natural Resources Defense Council, New York City, Washington.

Harris, R., Archer, L. \& Waltke, K., 1980, Theological wordbook of the Old Testament: The word edition, Moody Publishers, Chicago.

Heitink, G., 1999, Practical theology: History, theory, action domains, transl. R. Bruinsma, Grand Rapids.

Heyns, J.A., 1980, The church, N.G. Kerkboekhandel, Pretoria.

Heyns, L.M. \& Pieterse, H.J.C., 1990, A primer in practical theology, Gnosis, Pretoria.
Ingraffea, A., 2009, Expert: drilling impact two orders of magnitude bigger with no regs, reported by S. Smith-Heavenrich, viewed 12 November 2013 from http:// regs, reported by S. Smith-Heave
marcelluseffect.blogspot.com

King, J., 2012, 'Hydraulic Fracturing 101: What every representative, environmentalist, regulator, reporter, investor, university researcher, neighbor and engineer
should know about estimating frac risk and improving frac performance in unconventional gas and oil wells' presented at Society of Petroleum Engineers Hydraulic Fracturing Technology Conference held in The Woodlands, Texas, 06-08 February, viewed 06 November 2013 from http://www.apachecorp.com

Maslow, A., 1943, 'A theory of human motivation', Psychological Review 50(4), 370-396, viewed 31 January 2014, from http://psychclassics.yorku.ca/Maslow/ motivation.htm

McGrath, A., 2009, A fine-tuned universe, Westminster John Knox Press, Louisville.

Moltmann, J., 1985, God in creation, transl. M. Kohl, SCM Press, London.

Nel, E., \& Hill, T., 2008, 'Marginalisation and demographic change in the semi-arid Karoo, South Africa', Journal of Arid Environments 72(12), 2264-2274, viewed
24 October 2014, from http://www.sciencedirect.com/science/article/pii/ S0140196308002176

Norman, N. \& Whitfield, G., 2006, Geological journeys, Struik Nature, Cape Town.

Osmer, R., 2008, Practical theology: An introduction, Eerdmans, Grand Rapids.

Palmer, D., 2005, Seven million years, the story of human evolution, Weidenfeld \& Nicolson, London.

Stoddard, E., 2013, 'Minister says fracking vital for economy, energy needs', in Reuter's News Agency, viewed 31 January 2014 from http://www.reuters.com/ article/2013/10/10/safrica-fracking.

Steyl G., \& van Tonder G., 2013, Hydrochemical and hydrogeological impact of hydraulic fracturing in the Karoo, South Africa, InTech, Rijeka.

Tucker, A.R., 2011, 'Practical theology: Can it really help the local congregation?' HTS Teologiese Studies/Theological Studies 67(2), Art. \#884, 10 pages. http://dx.doi. org/10.4102/hts.v67i2.884

United States Department of Energy, 2011, 2013, Oil and natural gas report, National Energy Technology Laboratory, Morgantowninia.

Van der Ven, J.A, 1993, Practical theology: An empirical approach, Kok Pharos Publishing House, Kampen.

Van der Ven, J.A., 1994, 'Empirical methodology in practical theology: Why and how?', Practical Theology of South Africa 9(1), 29-44.

Vermeulen, P., 2012, 'A South African perspective on shale gas hydraulic fracturing', in C.D. McCullough, M.A. Lund \& L. Wyse (eds), International Mine Water Association Annual Conference, Institute for Groundwater Studies, University of Association Annual Conference, Institute for Groundwater Studies, University of the Free State, Bloemfontein South Africa, 2012, pp. 149-146, viewed 28 M
2014, from www.imwa.info/docs/imwa_2012/IMWA2012_Vermeulen_149

Wallace, M., 2001, 'Earth God: Cultivating the spirit in an ecocidal culture', in G. Ward (ed.), The Blackwell companion to postmodern theology, pp. 209-228, Blackwell Publishers Ltd., Oxford.

Welker, M., 1999, Creation and reality, Fortress Press, Minneapolis. 